\title{
Discourse Representation of Consumerism in Mobile Telecommunication Television Advertisements
}

DOI: https://doi.org/10.47175/rielsj.v1i2.84

\section{| Fredrick Friday John |}

\author{
Department of English, \\ Chrisland University, \\ Abeokuta, Nigeria \\ Proffysong@gmail.com, \\ fjohn@chrislanduniversity.edu.ng
}

\begin{abstract}
Telecommunication advertisements have bifurcating relations, functioning as a buoyant part of the capitalist market, and as instruments indexing consumerism, which bridges the gap between service providers and subscribers. Previous linguistic studies on the subject have focused on speech acts, mainly locutionary and illocutionary acts, and the lexical and stylistic resources in telecommunication advertisements. This study focuses on the representations of consumerism in MTN and GLO advertisements. The study adopts a model labeled as conceptualtextual meaning in advertisements, which annexes the principles of critical stylistics, pragmatic acts, and multimodality to analyse both textual and multimodal excerpts from ten (10) MTN and GLO television advertisements. These were downloaded from youtube, where they are streamed to reach a vast majority of internet users after they had been aired on mainstream television and cable stations. The study reveals that consumerism is the most pivotal feature projected in the advertisements of MTN and GLO. Advertisements and services are principally designed to condition choice of the subscribers to expand their consumptions. Consumerism is metaphorised, using food substances and materials co-opted from the socio-cultural milieus that condition the advertisements. Conceptual-textual functions like naming and describing, enumerating and exemplifying and prioritising, and direct acts, indirect acts, conversation, emotional and psychological acts, as well as the textual resources of inference, metaphor, reference, relevance, and metapragmatic joker are used extensively to show consumerism. The study concludes every service option is aimed at expanding consumerism, while the cost of services, interest, and use of the services are the shades of consumption of telecommunication services.

KEYWORDS

Conceptual meaning; consumerism; advertisement; metaphor; pragmatic acts
\end{abstract}

\section{INTRODUCTION}

Consumerism is central and pivotal to any meaningful advertisement as well as language. These two factors are bidirectional in the quest to make people want or condescend to buy products and services. Vasiloaia (2009) describes advertisement as an 'inevitable part of the modern capitalist consumer society'. This posits that advertisement aims at persuading consumers to patronise certain products by certain capitalist agents, first, by foregrounding the superior utilitarian value of a product in the face of other competitors. Producers employ advertisement as a strategy to make their products appear not only catchy, but also preferable to their prospective customers, using a gamut of linguistic and nonlinguistic or 
cognitive conceptual strategies. These strategies and features employed may achieve direct, indirect, eclectic or elusive functions. This is why Cook (1992:5) argues that advertisements can 'amuse, inform, misinform, worry (and) warn' customers, on the one hand, and emphasise change of behaviour of products, brand and consumers, on the other hand. Hence, it can be surmised that advertisements are involved with, and in most cases, set the pace for our daily commercial life (Vahid and Esmae'li, 2012:37, Davidson, 1992).

Davidson (1992: 3) opines that advertisements employ social language, since it is a genre whose technique is to aid persuasion. In a more direct sense, Davidson argues that it has its own "languages, customs and history". Two assertions are evident in Davidson (1992) that serves as the problems addressed in this present study. The first is the fact that advertisement has its own unique form and functions as a different genre in media communication. The questions here include, what are the particular features that differentiate it from other genres, are these features conceptually or textually represented, and how are they overtly or covertly portrayed in telecommunication advertisements? The second assertion is situated within the conception that advertisements are designed to organize people's perceptions and create structures of meaning and ideologies (Williamson, 1978:12). The obvious here is that the tool for achieving these functions is language and the manner of using it include: playing on/with words, manipulating or distorting everyday meanings, breaking or bending of the rules of language, making up new words, clichés or acronyms, among others. However, the question it generates is: how are they deployed in telecommunication advertisements? Vahid and Esmae'li (2012:36) clarify that these features, means and functions constitute as language power and ideology of producers, which are used to change people's behavior and thought, especially towards their products or services.

A couple of studies have been done on the concept of advertisements, ranging from general advertisements to MTN and GLO advertisements. Oduola's (2001) study explored the speech acts of advertorials in Nigerian Newspapers. The study, apart from limiting its scope to print media, focused only on Searles' pragmatic acts, particularly the illocutionary acts that advertisements perform. While it is a given that illocutionary acts are textually marked, the study did not state it, neither did it discuss the conceptual marking of illocutions. Esizimetor (2002) worked on the use of pidgin in advertisements. While pidgin as a main strategy used by merchants to appeal to a wider range of audience, and appeals also to telecommunication adverts, the study did not state it as a conceptual strategy for consumerism. Makinde (2007) focused on the pragmatic features of 'GLO' advertisements on television. She dwelled more on the locutionary acts, identifying phonetic acts, rhetic acts, as well as other paralinguistic strategies like kinesis, colour signification, proxemics, among others, as enhancement to advertisements for the purpose of excitement and humour. The study did not mention humour as a serious function (Billig, 2005), let alone a way of texturing consumerism.

Ihedigbo (2008) applied a socio-pragmatic framework in analysing MTN and GLO advertisements on bill boards and Newspapers. The study, among other significance, viewed the socio-cultural effects of advertisements and their illocutionary functions. The projection of social and cultural norms is, to an onerous extent, a consumerist strategy, which the study did not specify. Vahid and Esmaeli's (2012) study applied a critical multimodal discourse framework to explore advertisement images. The study did not focus on telecommunication advertisement, neither did it comment, particularly, on multimodality as a conceptual strategy for consumerism. Robert's (2013) patterned his study in line with Ebonugwu's (2001), identifying major conventions in electronic media and print advertisements. However, while Ebonugwu critiqued the language used, which 
exhibits some peculiarities different from everyday conversational usage, Robert addressed the language as persuasive, informative to consumers.

From the foregoing, it is evident that none of the above studies, particularly, applied the conceptual-textual approach to study MTN and GLO advertisements, and none directly or indirectly addressed the bidirectional representations of consumerism, which this present study focuses on. The aim is to investigate the conceptual-textual functions or meaning in the language of MTN and GLO television advertisements with a view to examining how the ideology of consumerism is conceptually and textually represented, using both linguistic and multimodal choices.

\section{LITERATURE REVIEW}

\section{Ideology and Consumerism}

Consumerism is, in nature, conceptual and ideological in advertisement. However, it has, in the undertone, ideology as its formative principle. Ideology is no longer an academic discipline; it is now an object of investigation widely relative to ideas, beliefs, and opinions [...] underlying patterns of meaning, frames of interpretation, world views, or forms of everyday thinking and explanation' (Verschueren, 2012:8). Some of these features condition the mapping of consumerism in advertisements or commercials. Another relative truth is that, within the scope of the welfare instinct of producers and service providers, there is a collective notion to maximise the spectrum of person's utility (Sen, 1979:476). For instance, in order to transform people's utility, the welfarist has to present alternatives or other benefits which people could choose from. The act of alternative provision is the move to influence one's decision. This also relates to the Aristotelian notion of 'eudoamonism', which translates to judging actions. To say that a system is eudaimonistic means that it is regarded as the desirable cause of action that should increase people's happiness. This is the level that consumerism operates as an ideology.

Hilton (2003:4) opines that consumerism is the doctrine of continual increase in the rate of consumption as a condition for a 'sound economy'. It is a description given to an increasingly commodified culture, which encourages enquiries and researches into "the mass market", or social class and interpretations of advertising and marketing, and the material culture of commodities (Hilton, 2003:5). Consumerism defines the entire goal of production; the goal of production is for people to buy and consume. This justifies that we are all consumers of variable products and services. Clarke (2010:2) views consumerism as an ideology of choice; choices are made in multifarious areas of human life in particular ways that formalise a schematic structure for choice making in a general sense. This is why Schwartz (2004:114) views choice as a 'psychological' phenomenon. But Clarke (2010:5) prefers to leave it as an ideology related to several ways of comprehending how choices are made at different levels of human endeavours. Making a choice from different products can be difficult, especially because it involves choosing from too many close alternatives in this age of neo-capitalism. But it is often important, consequential, and in most cases irreversible, since it either leads to utility or regret.

In view of the above, Gill (1994:2) opines that consumerism entails the producers' demonstration, to the consumers, that their needs are taking to account in production and ultimately use or consumption in the production process or service delivery. This is a way of displaying absolute capability to meeting consumers' requirements. However, it should be noted that 'Consumers have wider concerns about the description of products', (which) producers meet by 'giving natural, wholesome, light, low, traditional, pure' description of their products (Gill, 1994:3) most of the time through welfare, in the case of telecommunication services, promo or bonanza strategies. 


\section{Theoretical Orientations}

The study applies the Critical stylistics (CS) approach, enhanced by theoretical principles of multimodality and pragmatic acts. CS is a relatively new branch of stylistics, attributed to Jeffries (2007; 2010). Dogar (2013) posits that it is largely informed by the principles of critical linguistic and critical discourse analysis (CDA). In actual fact, Jeffries (2010) herself agrees that it is the fusion of 'critical discourse analysis (CDA) and stylistics,' and is used to emphasise actual social meaning, as viewed from the social co(n)text. As it stands, there is a one-to-one link between CS and CDA. But CS goes a little further to analyse reoccurring conventions foregrounded in texts. In other words, it is a stylistic way of doing discourse analysis. Hence, it is a form of radical stylistics that can be applied to politics, administration, leadership and management, journalism, advertisements, among other discourses, which have peculiar style, and use language in ways that reflect the patterns of social organisation in relation to hierarchy, power, hegemony, influence, manipulation, persuasion, among others. Of course, these are employed by political, economic or commercial power blocs.

While the above foreground it as a political phenomenon, CS is not only peculiar to political orientations. It treats all texts to be ideologically based and concerns itself, just like CDA, with the task of uncovering hidden ideologies in texts. To do this, Jeffries (2010) prescribes a set of analytical tools called 'conceptual-textual functions', which are the organised ways of representing world views in texts. These textual functions are: naming and describing, representing actions/events/states, equating and contrasting, exemplifying and enumerating, prioritizing, implying and assuming, negating, hypothesizing, presenting the speech and thoughts of other participants, and representing time, space and society. The tools mutually interact with theoretical principles like multimodality and pragmatic acts to annex their maximum meaning potentials, as represented in fig. 1 below.

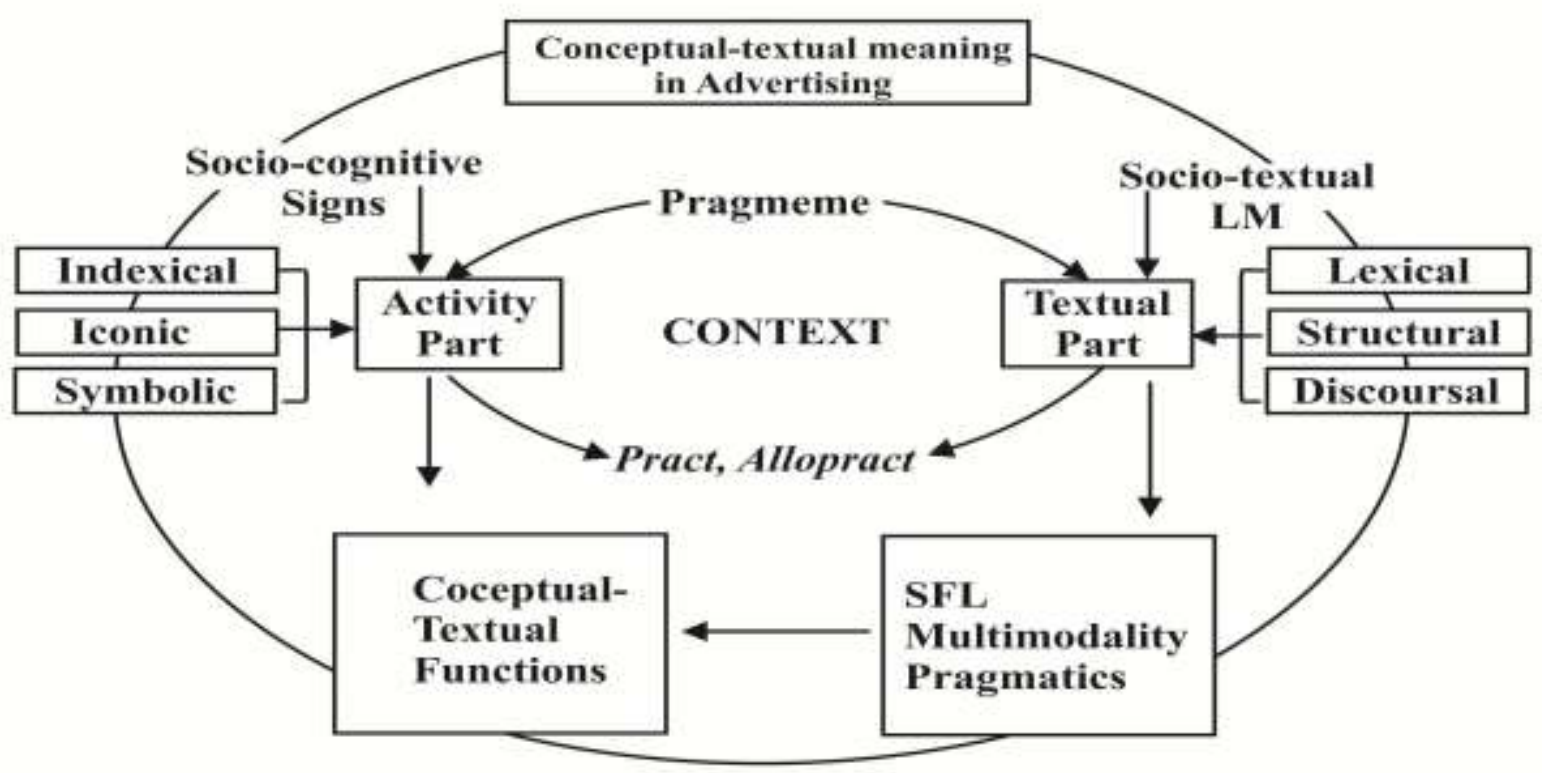

Figure 1. Conceptual-textual meaning in advertising (Source: John, 2017:41) 


\section{Pragmatic Act}

The pragmatic acts theory avers to the primacy of context in any instance of language use or interaction. It is associated also with the 'pragmene' of an utterance. Odebunmi (2015:201) opines that talk has a way of pointing out the context where the utterance has been made. In another instance, he opines that the (social) context summarily imposes or constrains meaning and understanding of events and (or) communicative encounters (Odebunmi, 2016:16). Going by Mey's (2001) assertion, 'context determines what one can say and what one cannot say'. This is also applicable to advertisements; the contexts of representation condition the texts; hence, cannot be detached from their interpretation or analysis.

Pragmatic acts go beyond the frontiers of the Austin's and Searles' models of the speech act theory. According to Mey (2001:41), the locutionary, illocutionary and perlocutionary variables of speech acts coagulate with co(n)text to, not only define specific actions (practs), but also to give utterances their true pragmatic meaning, which summarily allows them to count as true pragmatic acts. In a broader sense, pragmatic acts theory magnifies our views on the function language performs, and these functions, according to pragmaticians, are not constrained by the rules of grammar. Simply put, language performs specific functions and these functions are notable and activated by pragmatic acts, which provide the affordances for language users. Mayanga (1990:3) puts it that using an utterance means engaging in a certain kind of social intercourse whereby the utterer speaker, under a context, passes information to the hearer making him to accept certain conditions, opinion or discussion. These summarise the functions of language earlier stipulated.

There are two parts of Mey's pragmatic acts theory. These are: the activity part and the textual part. The activity part incorporates and is achieved by the principles of speech acts, indirect acts, conversational (dialogical) acts, psychological acts, prosodic acts and physical acts, while the textual part is realised by pragmatic concepts like inference (INF), reference (REF), relevance (REL), voice (VCE), shared situation knowledge (SSK), which Odebunmi (2006) modifies to shared cultural knowledge (SCK), metaphor (MPH) and metapragmatic joker $(\mathrm{M})$.

\section{Multimodality}

Multimodality deals with the deployment or portrayal of images in specific contexts in texts such as advertisements. Multimodal analysis means focusing, predominantly, on the message contents of images, frames, sounds and other audio-visual resources in a given text. Multimodality itself can be traced to Halliday's (1978: 192), which gives the notion that 'the grammar of a language is neither a code nor a set of rules for producing correct sentences, but a resource for making meanings.' Interestingly, the resources for making meaning are in both linguistic and non-linguistic terms. Language exists in forms of spoken, written, printed or digital media resources. Fairclough and Wodak (1997:164) argue that multimodality operates at the level of social semiotics, which is capable of drawing our attention to the multi-semiotic characteristics that most texts in contemporary society have and deploys in communicating meaning. The implication of this is that multimodality explores the ways of analysing visual images, and how the condition meaning, on the one hand, and the relationship between language and the visual images deployed, on the other hand.

It can be concluded that Multimodality plays a vital role in the production, reproduction and transformation of the social practices of our immediate society (Caldas-Coulthard and van Leeuwen, 2003). Kress and Van Leeuwen's (2006: 4-8) opine that for multimodality to 
be effective, it must 'involve an analysis of discourse, design, production and consumption' of images and visual elements as fundamental issues that are inherent the meaning making systems of the society.

\section{RESEARCH METHODS}

The data collection method is qualitative. This entails a purposive selection of a set of MTN and GLO television advertisements, which were downloaded from youtube video, a public domain where they are streamed as a complementary channel with mainstream television or cable stations. The data were evaluated based on the conceptual-textual resources and the mapping of the ideology of consumerism in the respective advertisements. The selected advertisements are: MTN extra data bundle, MTN yafun yafun bonus, MTN Pulse, MTN Family and Friends, GLO Free Tomorrow, Buka, GLO free tomorrow, Suya palava, GLO Data Service, GLO formula $4 x$ your recharge and GLO Campus Data Booster. These distributions are blends of piginised and anglicised advertisements. These were subsequently transcribed into texts and picture frames or multimodal plates for analysis. Translations were provided were necessary, using the social semiosis translation approach. The data were analysed using certain features in the analytical model in fig. 3.1 above. The features used are: multimodality, the conceptualtextual functions of Critical Stylistics (CS) as practs and pragmatic acts, both the textual and activity parts. The multimodal frame analysis is adopted for the analysis of the plates in the second section. This entails combining series of frames to tell the story or signify unfolding events or a sequence of narration in the text. This form of multimodal analysis is recommended for film or television advertisements analyses.

\section{RESULTS AND DISCUSSION}

The features of consumerism are analysed in two parts, the first part is labelled as textual representation of consumerism, while the second is labelled as consumerism through multimodal texts.

\section{Textual Representation of Consumerism in Advertisements}

Each MTN or GLO commercial or advertisement is targeted on attracting more consumers to consume, in this case, use the services offered by the service providers. This is the basis for consumerism, which is the crux, that is, the centre ideology of production and, subsequently, commercial advertising. The many ways that consumption or use of services are reflected or represented in advertisements, the indexes of Consumerism, in respective textual data are analysed below. Among these are the conceptual-textual functions of 'prioritizing, 'enumerating and exemplifying', conceptual metaphors using consumable substances like 'suya' 'drink' and other food substances.

\section{Excerpt:}

i. $\quad$...you go fit do anything! Wey you like with am; chatting oh, browsing

oh, texting oh, calling oh, to any network (MTN yafun yafun bonus)

Trans.: You can do whatever you want with it (airtime), be it chatting, browsing, texting and calling all networks.

The conceptual functions of exemplifying and enumerating are used to signify the act of consumerism. First, the excerpt exemplifies one of the ranges of services provided by the service provider. This is averred by the reference pronoun, am, which is the Piginised form of the neutal pronoun $i t$. It is anaphoric to airtime, which has been previously mentioned. Thus, it is also a conceptual function of naming. Following this, the excerpt enumerates the 
various options in terms of use that are open to customers to use the welfare service that is provided. These options are also correspondent in terms of relevance to the functions that telecommunication services provide. These features, as enumerated in the excerpt, are: chatting, texting, calling, and browsing. These features also exist at the metapragmatic scale of services for each mobile network. There is the inference that consumer - mobile phone users use the service for at least one of the enumerated features, which they reserve the right to choose.

The function of prioritising is represented in the indirect act, using the pragmatic-textual feature of inference in the infinitival, to any network. Here, the service provided by MTN is generalised to prioritise it to other rival services. The use of services is also referenced as a function of prioritising, the users have preference for services among the divide of the enumerated variables. whatever manner of use is required. The piginised clause, wey you like with am, which is translated as,' whatever you want with it,' shows the preference, that is, priority that users have for certain services, or one or more of the variables of use listed by the service providers.

\section{Excerpt:}

ii. A. Two brokoto... four round-about

B. Hmm- - -

A. Eleven pomo

B. Ehn ehn, twelve pomo

A. Two wraps of pounded yam and two wraps of pounded yam

B. And one juice

A. And one juice

A. madam give me money

B. I chop yesterday, I pay, why I go come pay today, no be free tomorrow...

Trans.: Why should I pay after I paid for yesterday's consumption. Is it not free tomorrow?

C. E ma bo, free tomorrow wa n bi (GLO free tomorrow, Buka)

Trans.: Everybody come in, there is free tomorrow service.

The excerpt is in the conversational - dialogical act. Speaker A, the canteen waitress initiates the turn with the conceptual-textual function of enumerating. She enumerates, using co-hyponymy, variables of food consumed that are used as metaphors to index consumerism. These food items span from the socio-cultural milieu, relating the event to the sociocultural context; hence. The use of the pragmatic feature of shared cultural knowledge. These local foods, having local descriptions such, as 'brokoto', 'round-about' and 'pomo', are metapragmatic jokers, taken from the Yoruba socio-cultural milieu, yet marking a wider sociological context, which the Yoruba is prioritised. Speaker B's initial turns, which also have the principle of repetition, used as reference, confirm, reinforce or repair the waitress' utterances to ascertain her order of consumption. There is shared knowledge between speaker A and B on the choice of consumption.

These food items are co-opted as metaphor to refer to the use of mobile telecommunication services. In this case, the customer, speaker B, is a symbolic metaphor for the subscribers, that is, users of the network services. The free tomorrow service, using the function of narrating and describing, is described as a welfare service that offers more consumption (services) than what was consumed the previous day. This presupposes the use of mobile phone service every day. It also constructs the opinion and poses the inference that the welfare benefit, free tomorrow, is the motivating force for the users' consumption, that is, use of the products. Speaker C's utterance is an invitation to passers- 
bye (subscribers) to patronise the GLO service because of the benefit of free tomorrow. The inference and opinion represented here is that the benefit of the service is an attraction, and relatively the enhancer for the service producers to get more people to consume their service, since they (the subscribers) enjoy free services.

\section{Excerpts:}

iii. A. yes I go put am: oga this suya plenty o... your money e fit pay for hand all- suya?

Trans.: I will put it. But this Suya is much; Do you have the money to pay for it?

B. See if you pay yesterday, you no dey pay today, na free tomorrow

na. (GLO Free Tomorrow, Suya Palava)

Trans.: If you paid yesterday, you do not need to pay today; it is free tomorrow service.

iv. Whatever airtime or data you use in one day, you can get double the amount back tomorrow to browse, text and talk to all network free! (GLO free tomorrow, Buka)

v. As your personal person, I don bring the entire airtime wey you use today, including the one wey you take follow blessing talk, browse, text wey you.......u fit use as your personal awuuf, wey you go take browse, text, call any network tomorrow... (GLO free tomorrow, who be Blessing)

Trans: As your service provider, I bring you sufficient, including bonus, airtime today for you to call, browse and text,

The apriori context for sample (iii) is at a suya point, where the consumer, while placing order for, has consumed a lot of suya, and does not want to pay for them, using the GLO 'free tomorrow' service as leverage. The physical-conversational act, is used in the excerpt, because it is a response to the suya seller's enquiry, if he could afford to pay for the services, both the ones consumed and the ones served for take home. Speaker B's response implies that there is a price for consumerism. The inference is that one way or the other, the service is paid for the previous day. These are represented using the conceptual function of representing time, using the temporal yesterday, today and tomorrow. The function of describing and prioritising is used to mark the suya, which is a metaphor for the service consumed. It is described as plenty and prioritised as an increase to the subscriber value of consumption 'today,' since it does not require payment.

In excerpt (iv) the direct act is used to emphasise on consumerism. The emphasis here is on use, which is at the centre of every service or welfare package that is offered to the consumers. The conceptual function of naming is used, in airtime and data, to identify the main connection between the service providers and the users or subscribers. Data is a meronymous item of Airtime, because the socially shared knowledge is that airtime can be converted to data. Every package is aimed at making the consumers buy airtime. Reference is established in the amount, which is also a naming feature, pointing at the means used in procuring the airtime or data. This is modified, using the feature of enumerating, in the adjective double. There is also representation of time, in one day, and tomorrow, to give the inference of consistency of of the service for the benefits ahead. Furthermore, the conceptual-function of enumerating is used to identify the variables of use of the services. Browse, text and talk are co-hyponyms in terms of functions of mobile 
telecommunication services, while talk is synonymous to call, used in the previous excerpt. The same significations are evident in excerpt (v).

\section{Excerpt:}

vi. A. If you kan recharge $\mathrm{N} 200 \mathrm{eh} .$. as a big babe that you is na

Dem go give you N1, 200! (Laughing)

Trans.: If you recharge with N200, as a mature lady, you will receive N1, 200

B. Eey! Eey! Bros, abeg show me the way na. (MTN yafun yafun bonus)

Trans.: hey! Please, show me how to get it.

In sample (vi), speaker A is a vendor advertising an MTN service to speaker B, a lady, who is indexical or referential to the subscribers. The psychological - emotional act is employed to spring surprise, representing the opinion of arousing her interest to buy and use the service, which is tantamount to consumerism. The role relation between and responsibility of the subscribers and service provider is established using pronoun reference, and the function of naming. The subscriber is referenced using the pronoun, you, in the second person, which represents the opinion that the service provider, referenced by the Piginised plural pronoun, dem, deals with the subscribers directly, upon use of their product. The function of enumerating and contrasting are used to quantify the value of what the subscribers buy for consumption, and the welfare benefit the service provider gives back for consumption. There is relevance established in the excerpt. For instance, N1200 is relevant to six times value of consumption of what the subscriber has invested in the service.

The aim, which is to arouse interest and surprise for the purpose of instigating consumption pays off in Speaker B's reaction. This is also a function of relevance, that is, the interface between the illocution and the perlocution Here, the prosody act is used along with the feature of representing action to stress the willingness of the subscriber. The pidginised word, bros, is a metapragmatic joker and establishes a shared cultural knowledge between the interactants. It is used to establish the greeting culture of people from the same culture and background or who share the same code. Also, there is shared cultural knowledge in the 'way'. In the context of use, it implies that the subscriber wants to join the mobiliser agent to subscribe and use the service so as to benefit from the welfare package.

\section{Excerpt:}

vii. Whichever you choose, you get amazing Extra value. Bundles are available in large and extra-large... MTN Extra data bundle)

viii. In this twenty - four seven upload, download, tweet it, post it, like it... ( $G L O$ data service)

In excerpt (vii), consumerism is linked with choice, which is always the starting point of consumption. The subscribers, as discussed in the previous section, has to choose among alternative services at various macro and micro levels. The macro is the choice among brands, while the micro has to do with the range of services available in each brand. The excerpt presupposes first that a choice is always made. The direct act is used to state an equating consumer benefits for every range of service chosen. Another inference - opinion generated is that the more money the subscribes choose to expend, the more consumption is enhanced, on the one hand, and the more welfare benefit is accessed by the subscriber; on the other hand. The conceptual functions of equating and contrasting are bidirectionally used to represent, in a measuring scale, the bundle, which is a naming feature in its own 
right. Large is equated with extra-large on the basis of benefit, while extra-large is used contrastingly as a superlative term. Extra-large is greater in size or figure than large. In this case, size is used, while figure is indirectly inferred. Airtime or data volumes are measured in terms of figure and not size.

In sample (viii), GLO welfare services are represented as enhancement strategies to consumerism. The textual function of enumerating is used to itemise the variables of functions that condition also the way subscribers consume or use the services provided by the service providers, or what the services are meant for. This is further established with the features of epiphora, each structure ending with the neutal pronoun, $i t$, which is both a pragmatic feature of repetition, indexed to internet or data services. This is also, indirectly a naming feature, and is used for emphasis, to draw attention to use of the service. There are conceptual functions of contrasting and emphasising established in the enumerated services. For instance, upload and download are contrasted, while tweet, post and like reflect the function of emphasising. These are features of relevance to and co-hyponyms of messaging (use) in twitter service. The conceptual function of representing time is used to stipulate the period of consumption, use of the service, the inference is that the service is for everyday use. Twenty-four seven presupposes the euphemistic service use of twentyfour hours use, seven days in a week.

\section{Excerpt:}

ix. it didn't matter whether they are cool or they are not cool, what's really matter is that they are having a network that permits them to showcase the character that they truly are (stream all the latest and hottest Jamz on music + @ \#10 only) a network that allows them to be who they chose to be in life... (\#1, 500 on Deal Zone valid for 7days) (MTN pulse)

The excerpt above shows that consumerism is constrained, in terms of use, to social contexts. The conceptual function of naming, describing and contrasting, and indirect acts are used to play down on the reputation of the service provider, in this case, MTN, while the function of prioritising is used to emphasise on the subscribers, for the purpose of consumerism. Naming is established by the reference pronoun, they, while contrast is established in the description, cool, or not cool. The inference, which is ironical, is that it is not the status of the service provider that matters in telecommunication service, but the consumption need of the subscribers. Thus, consumerism is portrayed as a status booster, showing that services are used to reflect their conditions and status. This is portrayed, using the function of describing in, the character that they truly are. Consumerism is also indexed to pricing, using the textual functions of naming, describing and prioritising. The latest and hottest are descriptively used in the superlative forms (a way of prioritising) to modify the naming device, jamz. This is a metapragmatic joker that relate the service to the youth. There is also the function of representing time, achieved with the temporal index, 7 days, which conditions the service to a stipulated time of use.

\section{Excerpt:}

x. A. nobody wants to leave campus because with GLO campus booster, you get eight times the value of your data when you are on campus... That means eight times chatting, browsing, pinging and more (GLO Campus Data Booster)

In sample $(\mathrm{x})$ the conceptual-textual function of naming is first established with the indefinite reference pronoun, nobody, to index or profile the users of the service. The use 
of the indefinite pronoun also constructs the opinion or inference that the network providers are more concerned with the use of their service than the personality of who is using the service. For instance, in the excerpt, the service is designed for the campus, which is also a function of naming, but subscribers, who are not students, are going there to use it. The excerpt also avers that consumerism is defined for specific class or status of people, though not restricted only to their use. In this case, the function of equating is premised. Nobody presupposes everybody, equating themselves with students, going to the tertiary institutions, which is the spatial index, also the conceptual-textual function of representing place, to use the service. The conceptual function of enumerating is subsequently used to itemise the meronyms of data services, chatting, browsing and pinging, which are the factors of consumerism of the network services, while generalisation is used to imply limitlessness of the ranges of consumerism.

\section{Consumerism through Multimodal Texts}

Consumerism is vastly portrayed, using multimodal resources of sign, indexes, icons and symbols, in Nigerian telecommunication advertisements, mostly in MTN and GLO. In most cases, the resources used are co-opted from the social and cultural practices of certain sociological milieus. This corresponds with the goal of the copywriter to arouse the interest of or appeal to the vast majority of willing subscribers. Instances of these are discussed, using multimodal frame analysis, which entails connecting frames in plates to tell the story or signify unfolding events in a sequence of narration.

\section{Excerpt (xi)}

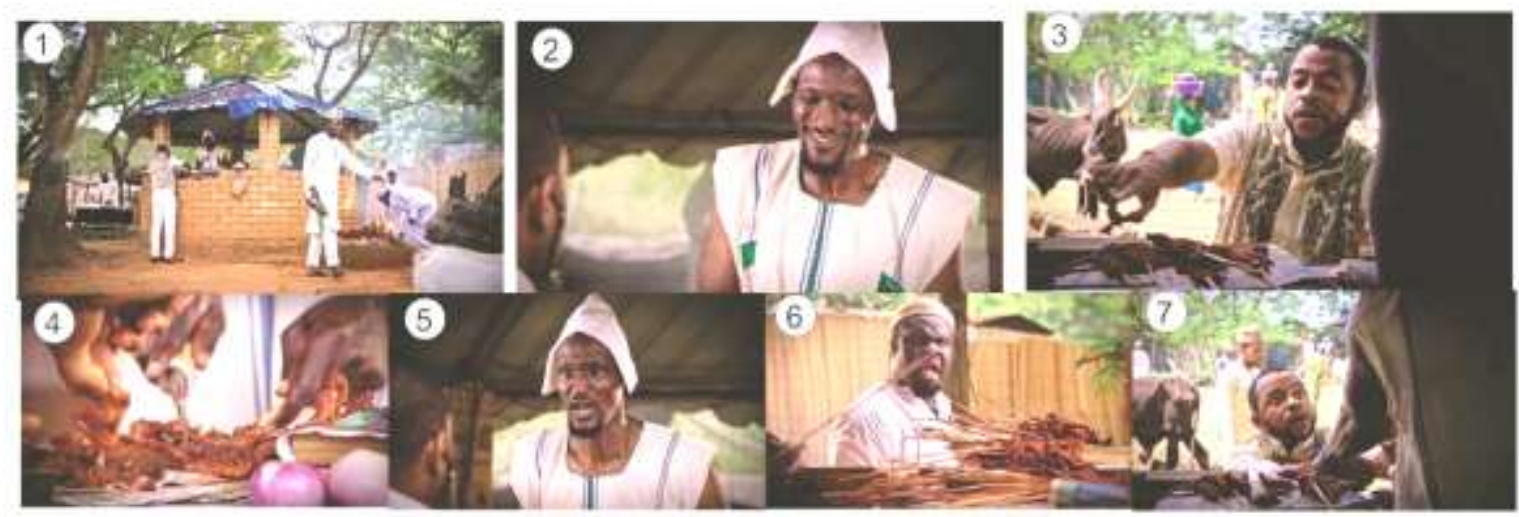

Figure .1 Seven plates from GLO free tomorrow, suya palava

In the above excerpt, consumerism is metaphorised using 'suya', as it is called in the sociocultural context. The consumer eating the meat symbolises the subscribers, while the suya vendor symbolises a rival network provider. The vendor is wearing a proper Hausa regalia as well as the other agents in the advertisements. The woman in plate (3) is dressed in 'ijaab', and is carrying a calabash, inferred to be cow milk, also metaphorising consumerism. The dominant colour code of GLO, which is green, is foregrounded in the vendor's outfit. However, the vendor's outfit contradicts his representation, because the he denies that his Suya joint is 'GLO suya spot' which implies that he is representing another network service provider not offering the advertised service. But the signification of the colour in his outfit is that the service, 'free tomorrow' is served only by GLO. At the background, we see also the umbrella tree covered with green leaves. Trees, in the conceptual sense, signify shelter, covering and life. In this case, the tree is sheltering the hut where the suya is sold and consumed. Its use here is not just to flag the atmosphere 
with the colour signification of GLO indicating the advertisement as its sponsored advertisement, but also to show that GLO services provide both the enhancing and welfare benefits that consumers need.

\section{Excerpt (xii)}

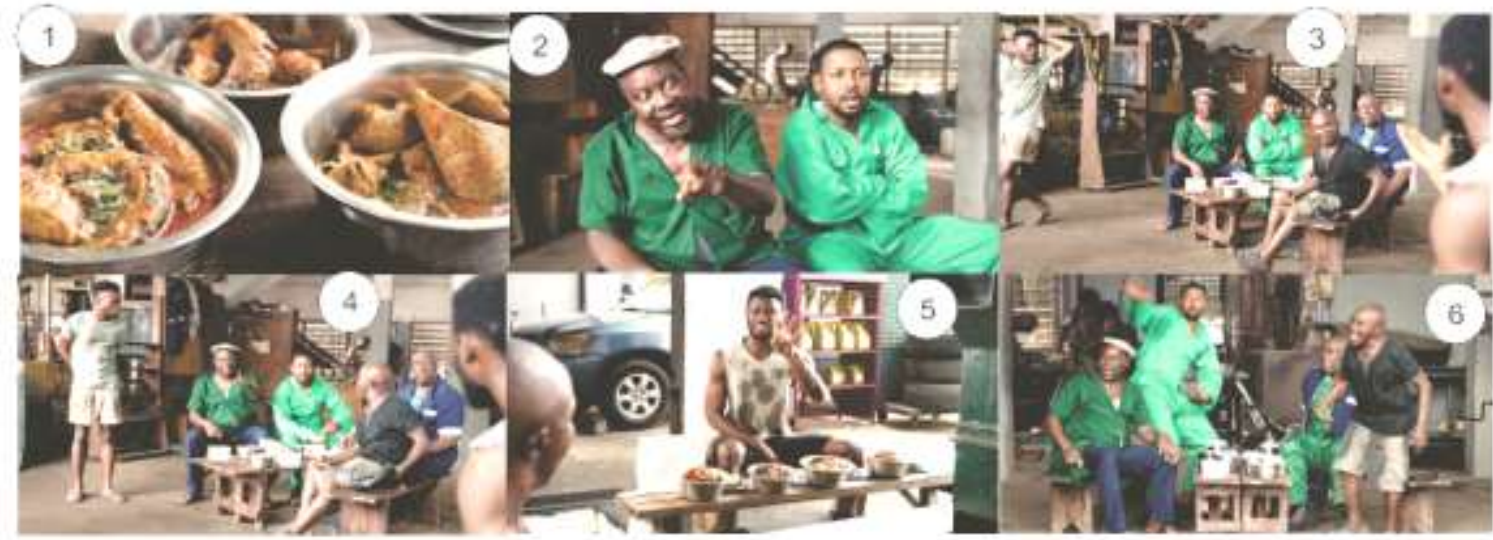

Figure 2. Six plates from GLO formula $4 x$ your recharge

The goal of the service provider here is to metaphorise consumerism using the experience of artisans. We see the proximal representation - placement of assorted food items, in this case 'fish' 'pomo' and 'meat' in plate (1). In plate (4) there are four dishes of food for each of the four superiors, while in contrast we have the same number of dishes for only one apprentice. The contrast in plate (4) shows that the four bosses are consuming less than the apprentice in plate (5) as a result of the saboteur apprentice cheating them. To locate the advertisement to the physical context, being a mechanic shop, objects like a broken-down vehicle, the gallons of automobile oil and tires are located in proximal way in plate (5), while two apprentices are backgrounded at distal locations in plates (2) and (4); their function is only to justifying the location.

\section{Excerpt (xiii)}

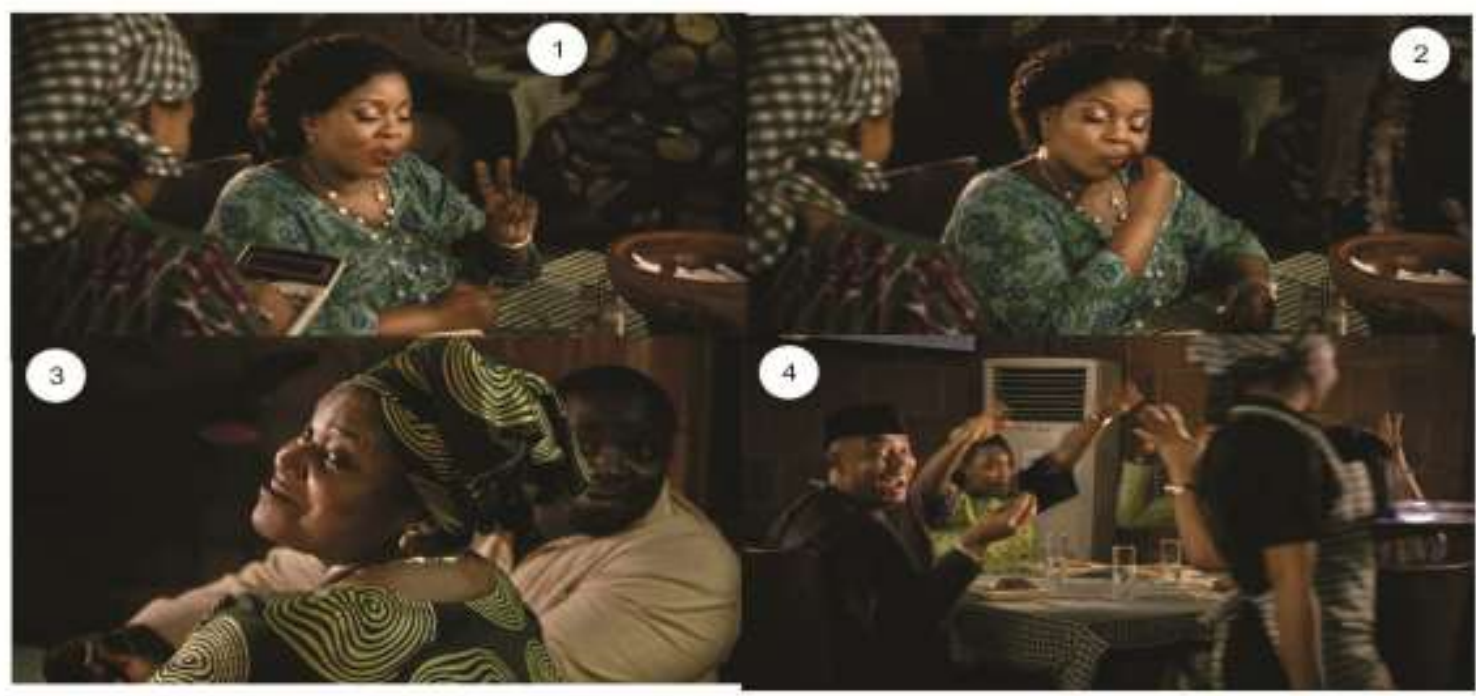

Figure 3. Four plates from Glo free Tomorrow, Buka 
The excerpt above also indexed the metaphorisation of consumerism using food, calculator and consumers in a food canteen, which is named in the title, using the pignised term, buka. In plate (1), the woman with the calculate, who is the food vendor, is an icon representing the service provider. She is holding a calculator, which another symbolic metaphor of consumerism, is used to calculate the consumer's consumption. It is also indexical to payment being requested from the consumer. The consumer is, using her fingers, gives a reference to the number of services consumed, while in plate (2), she is picking her teeth, to show that she has finished consuming the food, which is also symbolic to use of the service. The quantity of her consumption stirs amazement in plates (3) and (4). This is further iconised in two expressions. The first is bewilderment, by the man, while the second is excitement, which is iconised in the expression of the woman in plates (3) and (4). However, plate (4) expresses excitement to subscribe to the service by everyone in the buka. The conceptual function of equating is implied in the generalisation of the gender in the advert. This gives the inference that the service is designed for all gender and class of users.

\section{CONCLUSION}

The study has focused on the resources that mark consumerism in Nigerian telecommunication advertisements. Apart from the dominant significations, which are viewed from the domains of the conceptual-textual functions of CS, multimodality and pragmatic acts, there are generic conceptual and textual ways of representing the ideology of consumerism in television advertisements. First, telecommunication services are often represented as consumables, as seen in the multimodal plates, using particularly, food substances that are socio-culturally grounded. For instanc, suya, is grounded in the domain of the north, while pomo, brokoto, and round-about are indexed to the west. Other generic substances used include, calculator, colour significations, among others.

Consumerism services are defined using conceptual functions like enumerating, prioritising, naming and describing. The ranges of consumerism are enumerated to include: texting, calling, browsing, tweeting, talking, pinging, among others. These are the ranges of uses of the services provided by the service providers. It can be averred that every strategy and service represented in the advertisements are for the collective aim of defining consumerism. Consumerism is foregrounded as choice of use of the products, and consumers have to choose among various options. Consumerism is also represented as cost of services. Telecommunication services are attached to particular packages that involve payment. Consumerism is also represented as variables of use. Services are represented as having multifarious uses, as stated above. Consumerism is labelled as gender and class collectivism. Every service is portrayed as an attempt to bridge the gap between classes and gender.

Consumerism is mostly situated as a consumer ideology in telecommunication advertisements. Thus, the copywriters de-emphasise the status of the service providers, in some cases, to foreground the position of the users. Where the role of the service providers is foregrounded, they emphasise certain welfare packages that are connected to consumerism. For instance, eight times of data, twelve pomo, among others, served by the service providers are aimed at enhancing more consumption by the subscribers. Naming, describing, inference, reference and metaphor, among others, are used to situate both consumers' (subscribers') and service providers' roles. In other words, there is bidirectional roles between these two participants in relation to consumerism. The service providers, on the one hand, justify consumerism by providing more service options, while the users - consumers, on the other hand, pay for the services, because every service 
requires some form of payments, and the consume or use the services for various consumerist functions.

\section{REFERENCES}

Billlig, M. (2005). Laughter and Ridicule: Towards a Social Critique of Humour. Thousand Oak: Sage.

Caldas-Coulthard C and Van Leeuwen T. (2003). Teddy bear stories. Journal of Social Semiotics 13(1): 3-4.

Clarke, M. (2010). Challenging Choices: Ideology, Consumerism and Policy. London: Polity Press.

Cook, G. (1992). The Discourse of Advertising. London and New York: Routledge.

Davidson, M. (1992). The Consumerist Manifesto: Advertising in Postmodern Times. New York: Routledge.

Esizimetor DO (2002) A sociolinguistic exploration of the use of pidgin in advertising on two Nigerian print media. Master's project, University of Ibadan.

Fairclough N and Wodak R (1997) Critical discourse analysis. In: van Dijk T (ed.) Discourse as Social Interaction. London: Sage.

Gill, C. (1994). Food safety issues of consumer concern. In: Sheridan J, O'keeffe M and Rogers M (Eds.) Food Safety the Implications of Change from Producerism to Consumerism. Connecticut: Food and Nutrition Press.

Halliday, M. (1978). Language as Social Semiotic: The Social Interpretation of Language and Meaning. London: Edward Arnold.

Hilton, M. (2003). Consumerism in Twentieth-Century Britain: The Search for a Historical Movement. London: Cambridge University Press.

Ihedigbo, SI. (2008). A socio-pragmatic investigation of selected MTN and GLO billboard and Newspaper advertisements in Nigeria. Bachelor's project, University of Ibadan.

Jeffries, J. (2007). Opposition in Discourse. Basingstoke: Palgrave.

Jeffries, J. (2010). Critical Stylistics: The Power of English. Basingstoke: Palgrave.

John, F.F. (2017). Conceptual meaning and identity in the television advertisements of MTN and GLO. Ma Dissertation, University of Ibadan.

Kress, G and van Leeuwen T. (2006). Multimodal Discourse: The Modes and Media of Contemporary Communication. London: Edward Arnold.

Makinde, AA. (2007). A pragmatic study of selected GLO advertisements on television. Master's project, University of Ibadan.

Mayanga, AA. (1990). A semantic and pragmatic analysis of selected national day speeches of Nigerian heads of state. PhD Thesis, University of Ibadan.

Mey J. (2001). Pragmatics: An Introduction. Malden: Blackwell.

Odebunmi, A. (2015). You didn't give me to go and buy: Negotiating accountability for poor health in post recommendation medical consultation. Journal of Pragmatics 93(1): 1-15.

Odebunmi, A. (2016). Language, context and society: a theoretical anchorage. In: Odebunmi A and Ayoola K (eds) Language Context and Society: A Festschrift for Wale Adegbite. Ile-Ife: Obafemi Awolowo University Press.

Oduola, AO. (2001). A speech act analysis of advertorials in two Nigerian Newspapers. Master's project, University of Ibadan.

Robert, E. (2013). Language of advertising: A study of Nigeria's Nation Newspaper and Newswatch Magazine. Journal of Education and Learning 2 (3).

Schwartz, B. (2004). The Paradox of Choice: Why More is Less. New York: Ecco and Harper Collins.

Sen, AK. (1979). Utilitarianism and welfarism. Journal of Philosophy 76(1): 463-489. 
Vahid H and Esmae'Li S. (2012). The power behind images: Advertisement discourse in focus. International Journal of Linguistics 4(4): 36-51.

Vasiloaia, M. (2009). Linguistic features of the language of advertising. Available at: $\mathrm{http} / /$ search proquest.com/docview/845590429?accountid=33462 (Accessed 05 October, 2012).

Verschueren, J. (2012). Ideology in Language Use. London: Cambridge University Press.

Williamson, J. (1978). Decoding Advertisements: Ideology and Meaning in Advertising. London: Marion Boyars. 